\title{
Customer Relation in Knowledge Process Outsourcing
}

\author{
Akansha Sen ${ }^{1}$, Vivek Kumar ${ }^{2}$, Chinnappa Reddy Avula ${ }^{3}$, Vikas Kumar ${ }^{4}$ \\ ${ }^{I}$ (Department of Management Studies, LGOI, RGTU, Bhopal, India) \\ ${ }^{2}$ (Department of E \& C Engineering, LGOI, RGTU, Bhopal, India) \\ ${ }^{3}$ (Department of Management Studies, XLRI, Jamshedpur, India) \\ ${ }^{4}$ (Department of E \& C Engineering, PIT, RGTU, Bhopal, India)
}

\begin{abstract}
In the present scenario KPO has made a great progress in terms of supporting role of leading firms to newly established one. According to evalueserve, the share of the Indian KPO sector is expected to increase to 71 percent with revenues of USD 12 billion, by 2013. Evalueserve estimates that the Indian KPO market is expected to grow at a CAGR of 49.5 percent between 2003 and 2013, compared to a CAGR of 30.6 percent for the Indian BPO market, and a CAGR of 44.5 percent for the global KPO market, over the same period. The services sector accounted for about 51 percent of India's GDP in 2003, a figure that was much higher than 28 percent in 1950, and also one of the highest among the developing economies.

Outsourcing of high-end jobs is a win-win situation for both the end client and the KPO vendor. This paper presents basically a case study report on KPO. It includes the process of KPO, customer's relation, study and analysis of working of KPO. At the end it has been presented that how KPO maintains their customer relation and finally customer's satisfaction level is concluded.
\end{abstract}

Keywords - KPO, BPO, GDP, CAGR, Customer relation and satisfaction.

\section{INTRODUCTION}

The evolution and maturity of the Indian BPO sector has given birth to yet another wave in the global outsourcing scene: KPO or Knowledge Process Outsourcing. The success in outsourcing business process operations to India has encouraged many firms to start outsourcing their high-end knowledge work as well. Cost savings, operational efficiencies, access to a highly talented workforce and improved quality are all underlying expectations in off shoring high-end processes to India.

\section{The History OF KNOWLEdGe Process OUTSOURCING}

The KPO was started by McKinsey in India when it opened up a knowledge center back in 1987 which was then closely followed by the opening of research centers of companies like GE, Gartner and Office Tiger. However, it was not until 2006 to 2007 that KPO took off. KPO is considered as the third generation of the outsourcing revolution. IT Outsourcing is known as the first generation while Business Process Outsourcing or BPO represents the second wave which came in 2002 to 2003. During these years, outsourcing firms started to offer more than just telemarketing and sales; they offered more complex transactions such as decision-making and problem solving tasks. Four years later, firms began offering knowledge-intensive BPO services currently regarded as KPO services. The workforce also changed when KPO firms started to provide KPO services to different foreign and local businesses. The KPO workforce profile became more diverse as people with MBAs and those with medical, engineering, design, medical and specialist business skills were being hired by KPO companies.

KPO's central theme is to create solutions for clients by providing business expertise as opposed to BPO's aim to provide process expertise to clients. BPOs work with standardized processes, but with the shift to KPO, providers also shifted to offering processes that involve technical skills, analytical thinking and decisive judgment based on experience. India is undoubtedly still the biggest player in the IT, BPO and KPO fields, having had the advantage of being the first country to benefit from the IT outsourcing boom early on. India is also reported to have the biggest talent pool with an advantage of 15 years' experience over other countries' talent pool. India's workforce increases in number as young students graduate annually from some 400-degree granting institutions in the country. However, many countries such as the Philippines and China have appeared on the KPO map to provide KPO services to different foreign and local businesses. The lower cost of labor in India, the size of the talent pool, and the number of knowledge professionals are not the only bases of companies for choosing KPO firms that can provide them with the services they need. Businesses are looking at the scale and quality of the workforce, infrastructure, financial and risk environment, as well as the KPO firms' inclination toward identifying skill sets and workforce-related metrics. 


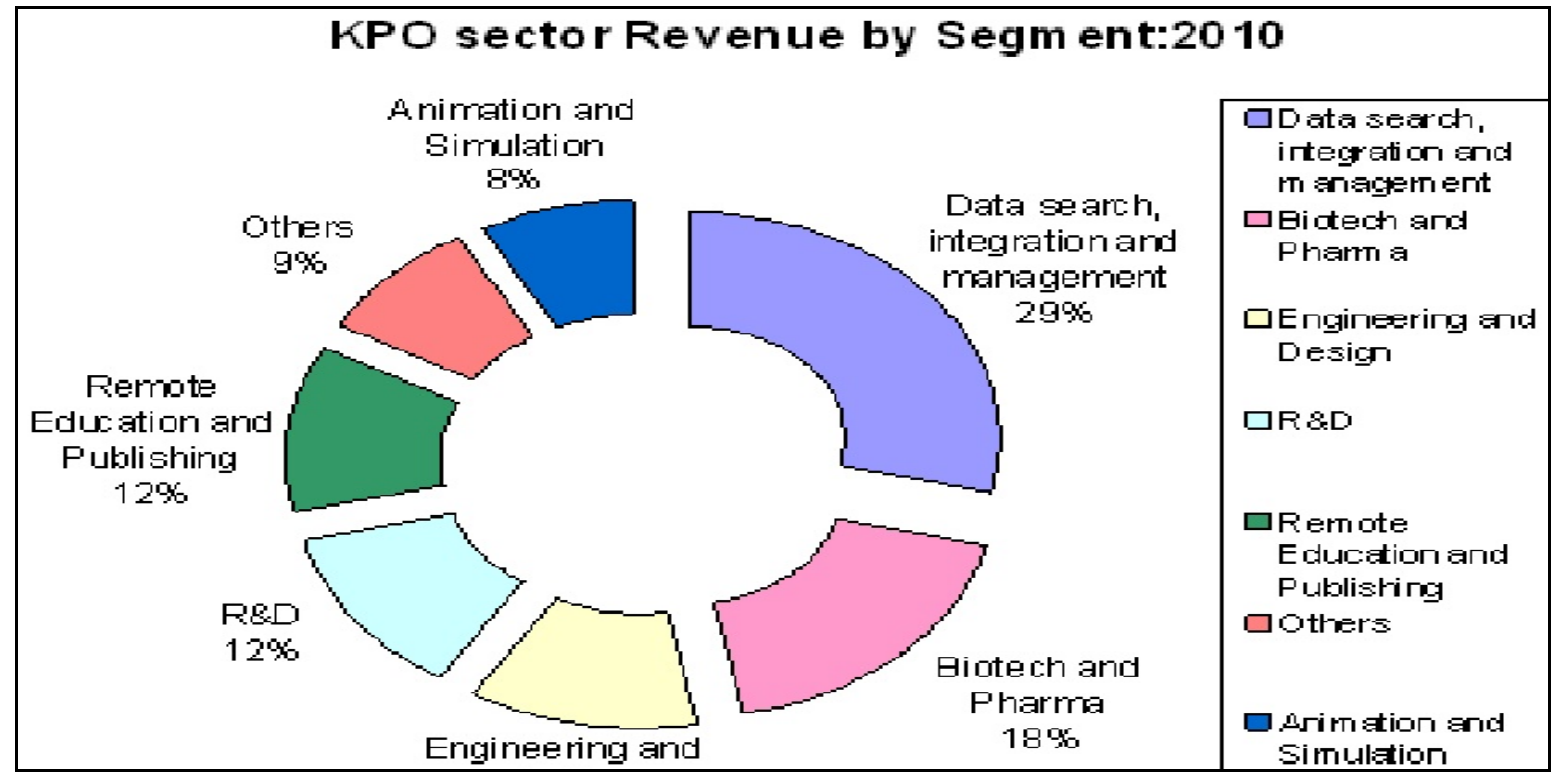

Fig 1:- KPO sector revenue by segment

III. OBJECTIVES OF RESEARCH

- Designation Study of customer relation in Ardent Knowledge and Research Services (KPO)

- To study the process of knowledge process outsourcing (KPO)

- To understand the KPO services provided by ardent knowledge research and services.

- To underline the satisfaction level among the customer served by ardent knowledge research and services.

\section{ReSEARCH Plan ANd Methodology}

Research plan refers to a conceptual structure within which research would be conducted. In our research, the research methods used were "Descriptive Research and Analytical Research". This work is based on the training undergone in Ardent Knowledge Research and Services "Study of Knowledge Process Outsourcing (KPO) and their customer relation", for KPO Analytical research we used the facts which are already available in the internet. The other research method was used is descriptive research as per the research topic we have to study their customer relation for that we used the descriptive research in which questionnaire method is used.

\subsection{Research Design}

STUDY OF KPO THROUGH INTERNET AND REPORT AVAILABLE

STUDY OF KPO AND THEIR CUSTOMER RELATION

STUDY OF ENVIRONMENT OF ARDENT KNOWLEDGE AND RESEARCH SERVICES

STUDY OF CUSTOMER RELATION INARDENT KNOWLEDGE AND RESEARCH SERVICES

DESIGN OF SUDY(SAMPLING, QUESTIONNARIE DESIGN)

INTERACTION WITH CUSTOMER

COLLECTING DATA THROUGH QUESTIONNARIE

ANALYSIS OF DATA AND INTERPRET FINDINGS

Fig. 2:- Steps of Research Design 


\subsection{Data Collection Method}

Generally Primary data are those which are directly collected from the field of investigation. These are collected by the researcher according to the plan way fixed up by him in the beginning of the project. They are collected for the first time and are then kept in the various forms for analysis purposes. In this research the following methods for the collection of primary data is used.

(A) Interaction Method- One to one interaction with customers of the company.

(B) Questionnaire Method- Questionnaires cost low and are free from the biasness of the interviewer.

Respondents have adequate time to answer the questions so the data is more reliable. The questionnaire contains 11 questions.

\subsection{Data Interpretation}

Following are data interpretation for each questionnaire.

Q1. From where did you get the information about the company?

As per the received data the $45 \%$ of customers get the information from internet, $25 \%$ from newspaper, $20 \%$ from their friends and rest $10 \%$ get the information from local channel. From the above result it can be said that the company must focus on their advertisement policy in local area for better result.

Q2. Did this organization meet your expectations?

As the data provided by the respondents the $69 \%$ of customers' expectations are full fill by the company and only $31 \%$ of customers are not satisfy with the company. From the above result the company should be more focuses on the $31 \%$ of customer who are not satisfied with the company performance. By doing this they will get better result in future.

Q3. According to the customer service provided rate the company?

As per the received data $67 \%$ of the customers said that the service provided by the company is average, $25 \%$ said that it is great 5\% said that it is outstanding and 3\% said that it is poor. As per the above interpretation the company should take their services seriously because the customers are not fully satisfied with their services.

Q4. Do you feel that there is a need of improvement in our customer services?

According to the analysis of data, $45 \%$ of customers said that the customer services provided by the company must be improved, $25 \%$ said that it is O.K and the rest 30\% don't want to say anything regarding the services.

Q5. Rate our representative's ability to resolve your issue.

As per the received data $35 \%$ of customers said that the representative good in solving their problem, $45 \%$ said that they are average in solving the problem and $15 \%$ of customer said that they are very good and 5\% says there is a poor services of representatives. Form the above result the company must try to improve their representatives' skills.

Q6. Are you satisfied with company's terms and conditions?

As per the received data $65 \%$ of the customers said that they are satisfy with terms and condition, $35 \%$ said that they were not satisfy with terms and conditions.

Q7. Is the data given by the company is relevant with your needs?

As per the provided data $65 \%$ of the customers said that the data given by the company is good and $35 \%$ said that it was not good. From the above interpretation it is clear that the company should be more focused in the data for their future business.

Q8. What are the suggestions you want to effectuate.

As per the received data $50 \%$ of the customers said that the COMPANY must disclose their data and policy clearly, $45 \%$ says that the company must provide after sales services and $9 \%$ says that they don't want to comment.

Q9. Describe your overall experience with our company.

According to the analysis of data, $35 \%$ of the customers said that there overall experience is satisfactory, $45 \%$ feels that it is average, $5 \%$ said that it is fantastic and $15 \%$ said that there must be some changes.

Q10. Would you recommend our services to other people? 
As per the received data $35 \%$ of the customers said that there overall experience is satisfactory, $45 \%$ feels that it is average, $5 \%$ said that it is fantastic and $15 \%$ said that there must be some changes.

Q11. Will you like to use our services in future?

As per the received data $33 \%$ of the customers said that they use their services in future, $53 \%$ said may be and $14 \%$ said no.

\subsection{Outcomes}

After the analysis of the data received from the customers, following findings were extracted:

- It is analyzed that the process is mostly based on the secondary data which may not be reliable.

- It was analyzed that the $45 \%$ customers said that the companies have a good relation with customers.

- $67 \%$ of customers said that the services given by the company is average.

- Only $45 \%$ of customers think that the company's representatives are able to solve their problems efficiently.

- $65 \%$ of customers said that data given by the company is relevant in nature.

- From the study it is analyzed that the process of the KPO is very time consuming.

\section{CONCLUSION}

KPO is the upcoming industry in India. The main purpose of any KPO is to provide good service to their customer. KPO are coming in many sectors such as Banking, Securities, Industry Research Services, Contract Research, Organizations and Bio-Pharmaceutical Services. A good KPO firm is likely to care more about the depth of knowledge and experience and the judgment skills of its professionals. The process of the KPO is difficult to understand, hence the KPO sectors are more focused to professional side. The client is involved during the entire execution process, client plays an important role in the KPO process, so it is necessary to understand the level of satisfaction they expect from the knowledge providers. To make growth in their business they can take feedback from their customer, whether they are satisfied or not. The data provided by the company under study is relevant in nature. The KPO is maintaining their customer relation very seriously for the future growth.

\subsection{Suggestions and Recommendations}

- It is concluded by the research that KPO is upcoming organization in India; hence in it there are huge career opportunities for both the entrepreneur and the job.

- It is suggested that the company must disclose their terms and condition properly and make it more transparent.

- It is concluded from the report the company is not taking its advertising strategy seriously, hence it is suggested that the company should be focus on their advertising policy.

- It is suggested that the company must take their representatives who are professionally skilled, as the company is knowledge provider hence it's imperative that representatives should be professionally skilled.

- It is found that communication skills of the representatives are not that good; hence the proper communication training must be given to all the representatives in order to have better understandings. From the analysis it is found that the customers of the company are not that much satisfied with the services, hence the company should conduct a program to take the suggestions from their customers.

\section{REFERENCES}

[1] Alok Aggarawal, “An Indispensible guide to investment in India facts and forecast”, Evaluserve Report, California, 2009.

[2] C.R. Kothari, "Research methodology methods and techniques" $2^{\text {nd }}$ edition. New age Publications, New Delhi, 2008

[3] Mukesh Chaturvedi, "Customer Relationship Management", 1 st edition , New Delhi, 2008

[4] Bala Bhaskaran, "KPO;A Shifting Paradigm", $1^{\text {st }}$ edition ,ICFAI Publications, 2007.

[5] Aberdeen Group, "Partnering for Performance: Knowledge Process Outsourcing”, January 2009. 